\title{
Developing guided inquiry-based ecosystem module to improve students' critical thinking skills
}

\author{
Irwan a,1, ${ }^{*}$, Maridi b,2, Sri Dwiastuti b,3 \\ a Master of Science Education, Faculty of Education, Sebelas Maret University, Jl. Ir. Sutami No. 36A, Surakarta, Central Java, 57126, Indonesia \\ ${ }^{b}$ Science Education Study Program, Faculty of Education, Sebelas Maret University, Jl. Ir. Sutami No. 36A, Surakarta, Central Java, 57126, Indonesia \\ 1 irwanforsmk@yahoo.co.id*; ${ }^{2}$ maridi_uns@yahoo.co.id; ${ }^{3}$ dwiastuti54@gmail.com \\ * corresponding author
}

\begin{tabular}{|c|c|}
\hline ARTICLE INFO & ABSTRACT \\
\hline $\begin{array}{l}\text { Article history } \\
\text { Received December 31, } 2018 \\
\text { Revised January 10, 2019 } \\
\text { Accepted February 23, } 2019 \\
\text { Published March 05, } 2019 \\
\text { Keywords } \\
\text { Critical thinking } \\
\text { Guided inquiry } \\
\text { Module }\end{array}$ & $\begin{array}{l}\text { The availability of modules that can develop critical students' thinking skills has not } \\
\text { been fulfilled. This study aimed to develop and determine the characteristics, feasibility, } \\
\text { and effectiveness of guided inquiry-based ecosystem modules to improve students' } \\
\text { critical thinking skills. This R\&D research referred to Borg and Gall model with nine } \\
\text { stages. The research instrument used was a test question sheet adapted from Facione. } \\
\text { The data gained were analyzed using ANCOVA. The results of the study showed that: } \\
\text { 1) the developed module was characterized with guided inquiry-based syntax and } \\
\text { critical thinking skills aspect; } 2 \text { ) the module was declared feasible based on the gained } \\
\text { validity scores i.e. } 92.19 \text { (very decent) from material expert, } 81.90 \text { (very decent) from } \\
\text { learning expert, } 78.57 \text { (worthy) from linguist, } 92.86 \text { (very decent) from learning media } \\
\text { expert, } 92.36 \text { (very decent) from practitioners, and } 91.80 \text { (very decent) from limited field } \\
\text { test; 3) the student critical thinking skills achievement which treated by using the } \\
\text { module was significantly higher compared to another class (F = 120.52; p-value <0.05). } \\
\text { It can be concluded that the developed module was feasible to be used in learning and } \\
\text { effectively improved students' critical thinking skills. } \\
\text { This is an open access article under the CC-BY-SA license } \\
\text { C. }\end{array}$ \\
\hline
\end{tabular}

\section{INTRODUCTION}

Critical thinking skill is one of the vital components (de Bie, Wilhelm, and van der Meij, 2015) and an important element in the 21 st-Century (Nusarastriya, Sapriya, Wahab, \& Budimansyah, 2013). Critical thinking skill has also become a serious discussion between educators and psychologists about the factors influencing in the students (Abdi, 2012). Critical thinking skill is quite important for students since it enables the assume, analyze arguments, and evaluate the quality of information (Bensley \& Spero, 2014). Critical thinking is a cognitive strategy and a way of looking at things and descriptive terms for a set of methods that are used to consider and solve problems effectively (Ismail, Harun, Zakaria, \& Salleh, 2017; Onions, 2009).

Students who have critical thinking skills tend to believe and act according to their reasoning logically and systematically based on the information received. Critical thinking skill consists of the ability in analyzing, 
understanding, and evaluating both reasons and information (Adeyemi, 2012; Dwyer, Hogan, \& Stewart, 2014; Shehab \& Nussbaum, 2015) and constitute is part of the cognitive skills consisting of interpretation, analysis, inference, evaluation, explanation, and self-regulation (Facione, 1992).

Critical thinking skill concerns the methods of thinking involving cognitive procedures such as reasoning, analyzing and evaluating that pedagogically related to problem-solving and communication (Arslan, 2015; Wilkin, 2017) and metacognitive processes covering several other components including skills in analyzing arguments, concluding skills through both inductive and deductive reasoning, skills in evaluating, and skills in making accurate problem-solving decisions (Lai, 2011; Sarigoz, 2012). Critical thinking skills as art in analyzing and evaluating thoughts to improve them (Serrat, 2017).

The development of students' critical thinking has been a concern and the primary goal of education in the world in the last few decades (Aliakbari \& Sadeghdaghighi, 2013; Larsson, 2017; Tabačková, 2015). The critical thinking skills development serves an essential role in the world of education and is needed by students (Visande, 2014). Teaching critical thinking skills has always been a learning-oriented goal for teachers in all disciplines (Thompson, 2011).

Increasing students' critical thinking skills should be the teachers' responsibility as stipulated in the Minister of Education and Culture of Indonesia regulation number 20 of 2016. The regulation confirms that students should have mastered some skills related both creatively, productively, critically, independently, collaboratively, and communicatively thinking and acting. The students who have critical thinking skills will be more easily explaining scientific concepts, solving problems, and exploring causal relationships from the occurring events around them. The learning process carried out in schools should at least be able to provide training for students' thinking skills, considering the significant impact of thinking skills owned by each student increases after the learning process takes place.

Students' critical thinking skills in Indonesia still need to be improved. The results of the Program for International Student Assessment (PISA) tests in 2015 showed that the average PISA score of Indonesian students was 395.3 on science, reading and mathematics so that Indonesia was ranked 62 out of 70 countries. Increasing the value of PISA can be done by improving the quality of education and high order thinking skills of students through the implementation of the curriculum 2013 (Sukardjo \& Sugiyanta, 2018). The results of the preliminary research and information collection in this study used instruments based on aspects of critical thinking skills in the matter of evaluating textbooks used in school learning on ecosystem material. The results of the analysis of evaluation questions on textbooks in the form of teacher handbooks and student handbooks showed that the average percentage in the interpretation aspect was $52.75 \%$, the analysis was $11.75 \%$, the inference was $13.75 \%$, the evaluation was $6.5 \%$, the explanation was $10 \%$, and self-regulation was $5.25 \%$. The results of the analysis show that the aspects of critical thinking skills used in learning at school are still low so that they have not accommodated students in developing their critical thinking skills.

Efforts that can be made to address the problems are by developing teaching materials. The development of teaching materials is one of the criteria that must be possessed by the teacher as stated in the academic qualifications and teacher competency standards. The Ministry of National Education of Indonesia stipulates it on regulation number 16 of 2007 which states that teachers in the senior high school level education units both in the demands of pedagogical and professional competencies are closely related to the teacher's ability to developing learning resources and teaching materials. The development of essential teaching materials is carried out by teachers. It can design learning to be more effective, efficient, and following the competencies to be achieved. Teaching materials can be developed in various ways and forms. One of the available teaching materials to be developed is a teaching module. Module development can be one solution to assist schools in realizing quality learning. Applying modules in schools can create a better planned, independent, complete, and produce clear output of learning activities. Modules are self-learning packages that include a series of learning experiences that are planned and designed systematically to help students achieve learning goals (Setiyadi, Ismail, \& Gani, 2017). A learning module is a self-contained, formally structured learning experience with a coherent and explicit set of learning outcomes and assessment criteria (Rufii, 2015). Modules can improve critical thinking skills as the results of research by Elisanti, Sajidan, and Prayitno (2018) which states that learning to use modules in the learning process is very significant to empower students' critical thinking skills.

This study aimed to develop and determine the characteristics, feasibility, and effectiveness of guided inquiry-based ecosystem modules to improve students' critical thinking skills. Guided inquiry-based learning contains learning activities that encourage students to analyze, solve problems based on facts found around them (Rusche \& Jason, 2011) and involve the participation of students actively in a series of learning experiences to find answers to problems that exist around them so that students construct their knowledge. Guided inquiry-based learning has a significant and effective in improving students' critical thinking skills (Elisanti et al., 2018; Nisa, Koestiari, Habibbulloh, \& Jatmiko, 2018; Zabit, 2010). Guided inquiry-based syntax namely: orientation, designing inquiry (formulating problems, formulating hypotheses, and collecting data) 
analyzing data, drawing conclusions, and communicating findings (Gengarelly \& Abrams, 2009). Guided inquiry-based learning is essential to apply to early-level students so that they use conceptual knowledge and their understanding to delve deeper into their ideas in the learning process (Jiun \& Nurzatulshima, 2014).

\section{METHOD}

This research and development using the Borg \& Gall procedures were modified in nine stages, i.e. (1) research and collecting information, (2) planning, (3) development of early product, (4) design validation, (5) main product revision, (6) limited field trial, (7) second product revision, (8) operational field trials, (9) the revision of the final product (Gall, Gall, \& Borg, 2003). The module's feasibility is guided by Table 1.

Table 1. Qualification of module feasible

\begin{tabular}{cc}
\hline Score & Category \\
\hline$>80-100$ & Very decent \\
$>60-80$ & Worthy \\
$>40-60$ & Quite decent \\
$>20-40$ & Not feasible \\
$0-20$ & Very unworthy \\
\hline
\end{tabular}

The operational field trial was conducted to determine the effectiveness of developed modules. The operational field trials using pretest-posttest control group design by McKenney and Reeves (2014) with experimental and control class. The operational field subject used was X MIA 3 and X MIA 4 class in Senior High School 1 of Karas - Magetan Regency in 2018. The sample was selected by cluster random sampling with two classes consisting of 29 students in the experimental class and 30 students in the control class. The experimental class was treated by conducting learning using a module based on guided-inquiry, while the control class conducted by learning using textbooks.

The research instruments used was 20 multiple choice questions and 10 essay questions adapted from Facione's critical thinking skills aspects which: (1) interpretation, (2) analysis, (3) inference, (4) evaluation, (5) explanation, and (6) self-regulation (Facione, 1992). The instruments used in this study have been tested for validity and reliability by 30 students. The data analysis used ANCOVA with a significance level 0.05 and preceded a prerequisite test, i.e. Shapiro-Wilk normality test and Levene's homogeneity test. The statistical analysis program used SPSS 21 for windows. The score categories of students' critical thinking skills showed in Table 2.

Table 2. Score category of students' critical thinking skills

\begin{tabular}{cc}
\hline Score & Category \\
\hline $81.25<X \leq 100$ & Very high \\
$71.50<X \leq 81.25$ & High \\
$62.50<X \leq 71.50$ & Moderate \\
$43.75<X \leq 62.50$ & Low \\
$0<X \leq 43.75$ & Very low \\
\hline
\end{tabular}

\section{RESULTS AND DISCUSSION}

\section{Stage 1: Research and information gathering}

The results of the analysis indicate that students' level of critical thinking skills is classified as very low (34.55). In more detail, five of the six components of critical thinking are in the shallow range $(0<x<43.75)$. The five components include (1) interpretation, (2) analysis, (3) inference, (4) evaluation, and (5) explanation with scores in a sequence of $41.14,32.70,25.45,22.54$, and 41.07 . Meanwhile, the student self-regulation component of 44.42 was classified as low. These results show that the learning process carried out so far has not been able to improve students' critical thinking skills. Thus, efforts need to be significantly able to help improve critical thinking skills. Critical thinking skills need to be improved because it is very fundamental in managing learning skills and empowering students to contribute actively and creatively to life. Students who have critical thinking skills are more comfortable to solve problems in their lives. Students' critical thinking skills are able to explain causal relationships from events that occur around them (Aizikovitsh-Udi \& Cheng, 2015).

\section{Stage 2: Planning}

The planning phase begins with determining learning objectives based on core competencies (or kompetensi inti/KI) and basic competencies (or kompetensi dasar/KD). The results of this stage stipulate that the material developed in the module is an ecosystem. The material is analyzed and adapted to the curriculum 
used in the school to determine the level of student achievement after learning occurs. The module matrix preparation phase is carried out after the goal setting stage. The focus at this stage is to adjust the activities planned in the module according to guided inquiry syntax with aspects of critical thinking skills.

The next step is to determine the guided inquiry-based module format and the format of learning devices that include it. The module format developed includes four sub-topic, i.e. (1) ecosystems and their constituent components, (2) interactions between organisms in ecosystems, (3) food chains and food networks, and (4) biogeochemical cycles, while the format of learning devices used in structured modules the syllabus and plan for implementing the learning that is prepared based on the curriculum applied in the school.

In addition to these four components, the last step is to determine the procedure for developing modules such as determining the subject of research, data collection techniques and all data needed in module development starting from initial product design development, product validation, to product testing.

\section{Stage 3: Development of initial product draft}

The module prototype design was developed by referring to the syntax of critical thinking skills. At this stage, aspects of developing learning objectives, developing indicators, designing learning activities, and evaluating are integrated into the module. The results of this stage are printed module prototypes.

\section{Stage 4: The product draft trial phase}

The module prototype testing phase is carried out by involving several expert validators. Validation carried out in the development of this module included material expert validation, expert device learning validation, validation of readability by linguists, and media validation and module design. The results of expert validation can be seen in Figure 1. The results of module validation indicate that guided inquiry-based products are feasible for use in learning.

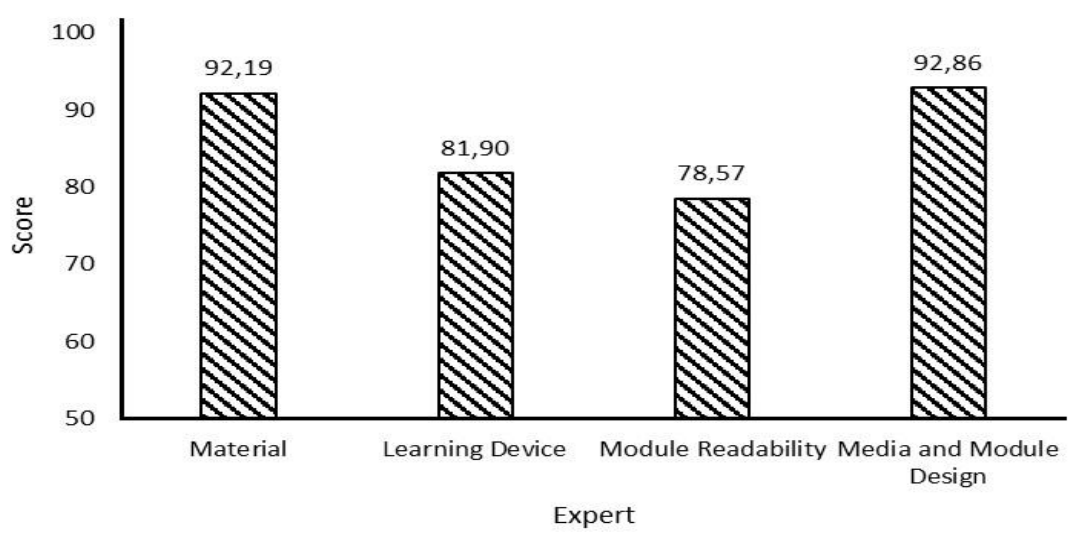

Figure 1. Daigram of the results of module validation by expert

\section{Stage 5: The first product revision}

Improvement suggestions from experts were used as the basis for developing the module. Some suggestions and corrections made to the modules developed as presented in Table 3. Based on Table 3, the modules need to be improved and refined to minimize conceptual errors.

Table 3. Suggestions provided by expert and correction actions taken

\begin{tabular}{|c|c|}
\hline \\
\hline Suggestion & Correction \\
\hline $\begin{array}{l}\text { Reading the material in learning activities must } \\
\text { "implicitly" explain the components of teaching material. }\end{array}$ & $\begin{array}{l}\text { Revise the reading material in learning activities } 1 \text { with a more implicit } \\
\text { explanation about the teaching material components. }\end{array}$ \\
\hline $\begin{array}{l}\text { Make sure the teacher module can play an optimal role } \\
\text { in controlling student modules. }\end{array}$ & $\begin{array}{l}\text { Revise the learning activities in the teacher module and student modules } \\
\text { so that can play an optimal role in controlling the student module. }\end{array}$ \\
\hline $\begin{array}{l}\text { Note the suitability of guided inquiry syntax in the } \\
\text { teacher module and student module. }\end{array}$ & $\begin{array}{l}\text { Revise the suitability of syntax of guided inquiry learning in teacher } \\
\text { modules and student modules. }\end{array}$ \\
\hline \multicolumn{2}{|r|}{ Learning device } \\
\hline Suggestion & Correction \\
\hline $\begin{array}{l}\text { Each material indicator must represent to basic } \\
\text { competency. }\end{array}$ & Revise material indicators and make sure represent to basic competency. \\
\hline $\begin{array}{l}\text { Evaluation of modules must represent to material } \\
\text { indicators }\end{array}$ & Revise the evaluation and make sure it represents material indicators. \\
\hline
\end{tabular}




\begin{tabular}{|c|c|}
\hline \multicolumn{2}{|r|}{ Module readability } \\
\hline Suggestion & Correction \\
\hline Sub-chapter that are made hopeful of spelling. & Revise the spelling of sub-chapter. \\
\hline The caption in the module does not exist. & Write a description of the image contained in the module. \\
\hline $\begin{array}{l}\text { Examine the writing of word absorption elements with } \\
\text { standard vocabulary. }\end{array}$ & $\begin{array}{l}\text { Revise the writing errors of the word absorption elements and standard } \\
\text { vocabulary. }\end{array}$ \\
\hline \multicolumn{2}{|c|}{ Media and module design } \\
\hline Suggestion & Correction \\
\hline Writing copyright on the Francis page to remove it & Eliminate copyright writing on Francis pages. \\
\hline $\begin{array}{l}\text { The module cover image must include the source library } \\
\text { the image in the module so that the source of the library } \\
\text { and the description of the image are included }\end{array}$ & $\begin{array}{l}\text { Lists the source of the image library on the front cover of the module. } \\
\text { Lists the library sources and captions in the image in the module. }\end{array}$ \\
\hline Describe the general description of the subject matter. & Describe a general description of material to in the sub-chapter. \\
\hline Give clear instructions on each student's activities. & $\begin{array}{l}\text { Provide clear instructions on each student's activities in the student } \\
\text { activity sheet. }\end{array}$ \\
\hline
\end{tabular}

\section{Stage 6: Limited field trial stage}

The limited field-testing phase is carried out to determine aspects of qualitative data from the module readability. Testing is done intentionally to find out the various shortcomings contained in the module such as typos, typo letters, and errors in image layout and so on. This stage also aims to determine students' understanding of the contents of the module. The limited field-testing phase was carried out on education practitioners and 16 students who were randomly selected. The results of the limited field trial stage are presented in Figure 2. The assessment of educational practitioners is in the range of $80-100$, as well as the results of student evaluations with a score of 91.80 . The results of this limited field trial stage indicate that the module is feasible to use.

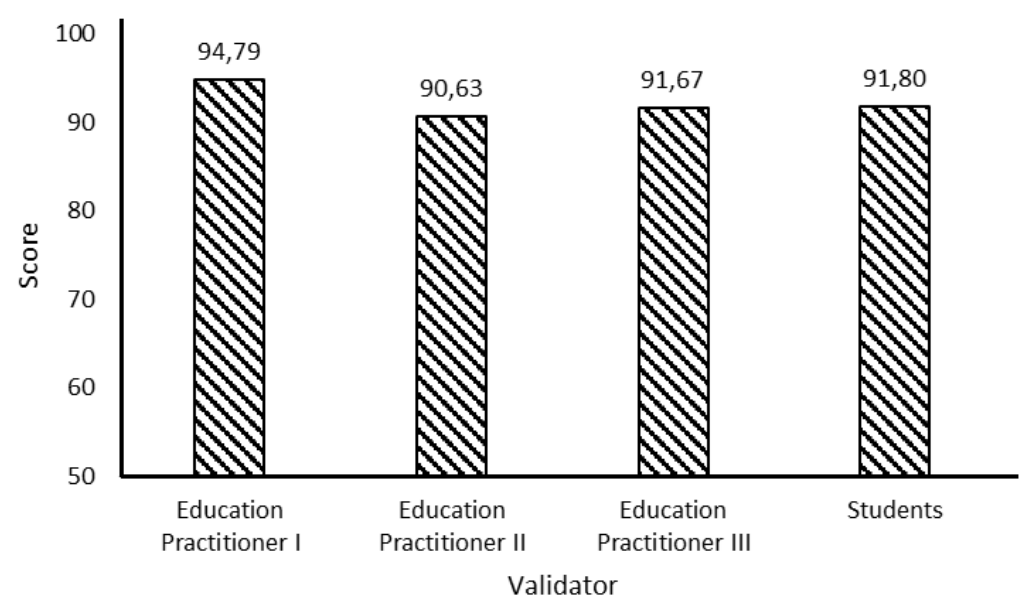

Figure 2. Chart of limited field trial stage results by education practitioner and student

\section{Stage 7: The second product revision}

The second revision is done by correcting and completing the errors and shortcomings of the module. The errors and shortcomings of the module are obtained from criticism and suggestions and input from education practitioners and students who conduct limited field tests, suggestions and input are then followed up by making improvements to the developing module. A summary of suggestions and corrections is presented in Table 4 and Table 5. The results of the second revision are used for the development of the next stage to produce a guided inquiry-based module that is used in learning to improve students' critical thinking skills.

\section{Stage 8: Operational field trial}

This phase begins with validating the instruments used in the study. The results of testing the validity and reliability of the instruments as outlined in Table 6 . The results of the validity and reliability tests indicate that the test instruments used are valid and reliable because of the value of $r_{\text {count }}>r_{\text {table. }}$. Furthermore, the results of the operational field trial stage in the form of assessing students' critical thinking skills were analyzed using ANCOVA. The results of the statistical analysis show that the $F_{\text {count }}$ was 120.52 with a significance level of 0.00 $(a<0.05)$. These results indicate that there are significant differences between the experimental classes using guided inquiry-based modules with the control class using textbooks in schools. These results indicate that the use of guided inquiry-based ecosystem modules is effective in empowering students' critical thinking skills. The 
difference between the posttest results of students in the experimental class shows that the module developed is based on aspects of students' critical thinking skills applied to the ecosystem material.

Table 4. Suggestions provided by education practitioners and corrective actions are taken

\begin{tabular}{ll}
\hline \multicolumn{1}{c}{ Suggestion } & \multicolumn{1}{c}{ Correction } \\
\hline The writing procedure and placement of the images are noticed and & Make corrections to the sequence of writing sentences and \\
the subject matter is expanded again. & clarify the image on the module and expand the material. \\
Writing scientific names are italicized and enlarged. & Make corrections to scientific naming and enlarge images. \\
\hline
\end{tabular}

Table 5. Suggestions correction is given by students and corrective actions taken

Suggestion Correction

\begin{tabular}{ll}
\hline \multicolumn{1}{c}{ There are a number of errors in writing words in modules that are } \\
$\begin{array}{l}\text { caused by several things, such as typos, font sizes that are not } \\
\text { diverse, and image sizes that are not large enough to be less } \\
\text { obvious to students. }\end{array}$ & $\begin{array}{l}\text { Correcting errors in the intended writing and increasing the } \\
\text { size of the image to make it more visible to students. }\end{array}$ \\
$\begin{array}{l}\text { There are several terms and abbreviations that are still considered } \\
\text { foreign by students. }\end{array}$ & $\begin{array}{l}\text { The terms and abbreviations referred to are explained on the } \\
\text { glossary page contained in the module. } \\
\text { A less attractive cover image. }\end{array}$ \\
\hline
\end{tabular}

Table 6. Recapitulation of the results of validity and reliability test items

\begin{tabular}{ccccc}
\hline Q Item & N & N Item & Validity & Reliability \\
\hline MCQs & 30 & 20 & $100 \%$ & $0.873>0.361$ \\
Essay & 30 & 10 & $100 \%$ & $0.708>0.361$ \\
\hline
\end{tabular}

\section{Stage 9: Revision of final product}

Based on the operational field-testing phase that has been carried out, the guided inquiry-based ecosystem module is deemed feasible to be used as teaching material to improve students' critical thinking skills without further revisions or improvements. However, evaluation still needs to be done to improve module quality. The evaluation and improvement phase of the module is carried out through the process of disseminating modules to education practitioners. The evaluation phase aims to get criticism, suggestions, and input to improve the final product to be ready for use by product users.

The distribution of evaluation sheets was carried out to three middle school biology teachers by providing a guided inquiry-based ecosystem module and accompanied by an assessment questionnaire related to the content in the module. The results of the teacher's response to the guided inquiry-based ecosystem module are presented in Figure 3. The teacher's response to the module obtains the average value included in the excellent category. Based on these results it can be concluded that the modules developed are feasible to be used in learning activities at the secondary school level.

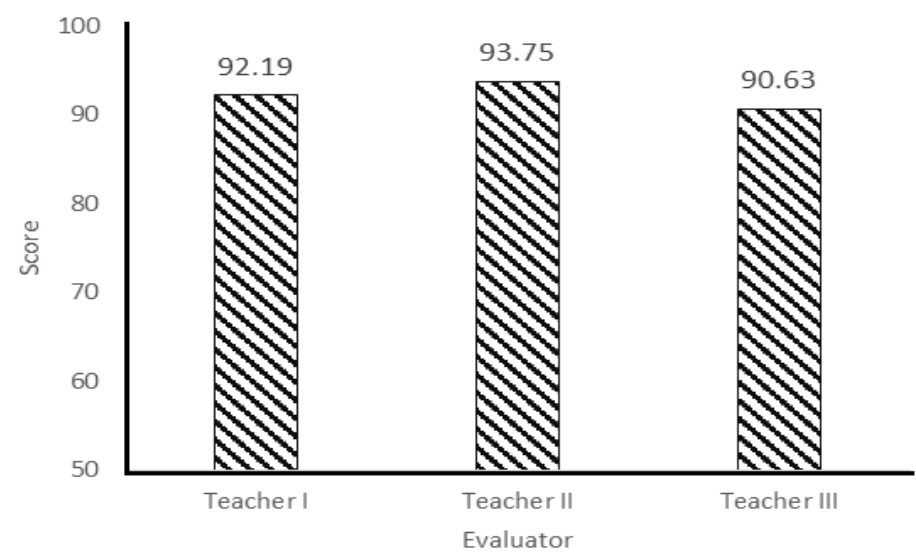

Figure 3. Chart of teacher response to the module developed by the teacher

\section{The guided inquiry-based modules characteristics}

This module is developed based on the principle of independence. Students are conditioned to be able to interact with learning materials actively and carny out various learning activities and get feedback about what they are learning (Rufii, 2015). The module developed contains (1) clear learning objectives and can describe the achievement of $\mathrm{KI}$ and $\mathrm{KD}$, (2) learning material that is packaged in specific activity units so that it is easy to 
learn thoroughly, (3) available examples and illustrations support the clarity of the presentation of learning material, (4) there are practice questions and assignments, so make it possible to measure the mastery level of student, (5) contextual, the material is presented related to the atmosphere, tasks and context of student activities and environments, (6) using communicative and straightforward language, (7) there is a summary, (8) there are assessment instruments, (9) there are assessment instruments, (10) there is feedback on student assessment, so students know the level of mastery of the material, and (11) there is information about referrals, enrichments, and references that support learning material (Nisa et al., 2018; Rusche \& Jason, 2011).

\section{Feasibility of guided inquiry-based modules}

The module feasibility to improve students' critical thinking skills were tested through validation by experts. The results of the material expert validation obtained an average value of 92.19 (very decent) category. Based on these results, it can be concluded that the material presented in the module has been declared feasible to apply. The ecosystem material contained in the module meets the criteria and feasibility based on the assessment indicators provided by the expert. Assessment indicators consist of several aspects including the completeness of the material, the material accuracy, activities that support learning, material upgrading, material strength in improving students' scientific competencies, material systematics, and material abilities in accommodating students' critical thinking skills.

The results of the expert device learning validation obtained an average value of 81.90 with very decent categories. Based on these results it can be concluded that the learning device developed has been declared feasible to be applied in the module. Learning devices designed in the module have met the criteria and feasibility based on assessment indicators by experts. Assessment indicators consist of the formulation of material indicators, the selection of material, the selection of sources and media, approaches and methods, assessment of learning outcomes, question material, presentation of questions, scoring, and aspects of students' critical thinking skills. However, the linguist validation obtained a mean value of 78.57 (worthy) category. On such a result, the language format and readability presented in the module are proper. Readability design of the module developed has been declared feasible and fulfills the criteria based on the indicator of inquiry by experts. Assessment indicators consist of the suitability of the language with the level of student development, communicative, and coherence and unity of ideas.

The results of the learning media expert validation obtained an average value of 92.86 with a very decent category. Based on these results, it can be concluded that the format of the design and graphics presented in it has been declared feasible to be used in the module. The design module has been declared feasible and fulfills the criteria based on expert indicators. The assessment indicators consist of public presentation organizations, considering the meaning and benefits, involving students, general appearance, information delivery techniques, the anatomy of modules developed, and observing the code of ethics and copyright.

The results of limited field testing for education practitioners obtained an average score of 92.36 with a very decent category. Based on these results it can be concluded that the guided inquiry-based ecosystem module developed is very feasible to use in classroom learning activities. The results of limited field tests by students obtained an average score of 91.80 which was categorized as very good. According to the results, an inquirybased ecosystem module developed was declared suitable for use in learning activities. However, the effectiveness of the module toward improving students' critical thinking skills in the experimental class was 83.66 with a very high category and a control class of 69.24 with a moderate category. More specifically the average value of students' critical thinking skills in each aspect is presented in Figure 4.

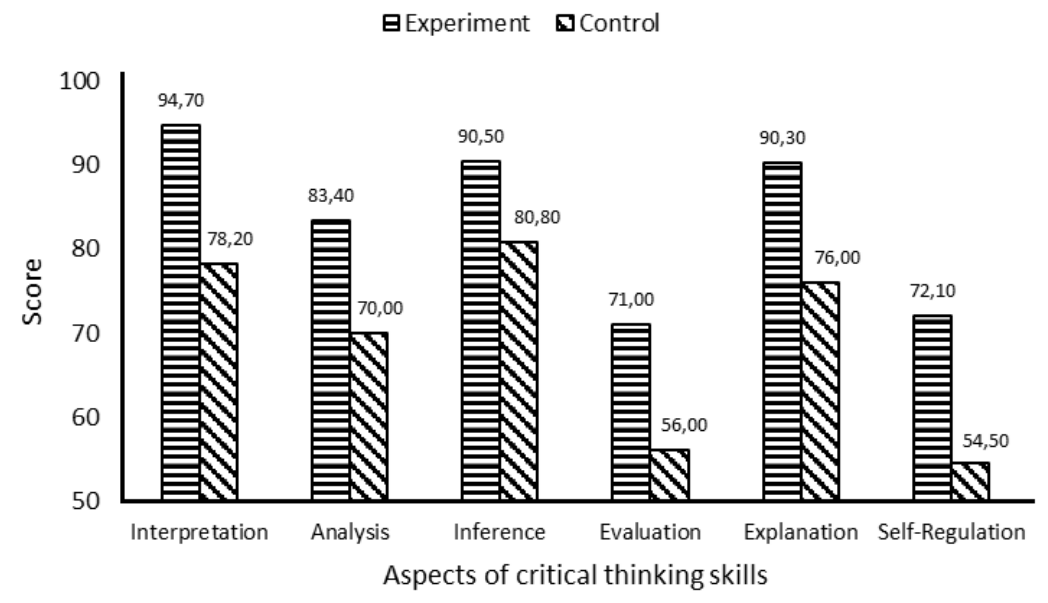

Figure 4. Chart of recapitulation of students' critical thinking skills scores by aspects. 
Moreover, the results of the preliminary test using the normality and homogeneity tests in the experimental class and the control class indicate that the data are spread normally and homogeneously. Based on Table 7, it can be concluded that the normality test using the Shapiro-Wilk test showed that the pretest and posttest were normally distribute $(\alpha>0.05)$, while the Levene's homogeneity test in all classes showed homogeneous pretest and posttest because of the significance level $(\alpha>0.05)$.

Table 7. Recapitulation of the results of the normality and homogeneity test

\begin{tabular}{lccc}
\hline \multicolumn{1}{c}{ Class } & Test & Type of test & Result \\
\hline Exp. & Norm. & Shapiro-Wilk test & Sig pretest 0.601; Sig posttest 0.07 \\
Ctrl. & Norm. & Shapiro-Wilk test & Sig pretest 0.074; Sig posttest 0.446 \\
All Class & Homogeneity & Levene's test & Sig pretest 0.903; Sig posttest 0.094 \\
\hline
\end{tabular}

. The next test conducted is the ANCOVA to determine the difference in posttest values in the experimental class and the control class. Based on Table 8, there is a significant difference between the posttest value between the experimental class and the control class $(a<0.05)$. Guided inquiry-based ecosystem module effectiveness in improving students' critical thinking skills is 0.683 or $60 \%$ (Waluyo, Prayitno, \& Sugiyarto, 2017). Improving students' critical thinking skills through learning using guided inquiry-based modules in this study is in line with research by Prihatin, Prayitno, and Rinanto, (2017) which states that the use of guided inquiry-based modules is effective in improving students' critical thinking skills. Guided inquiry-based learning activities implemented in modules can direct students to be directly involved in the learning process and provide opportunities for them to understand material concepts more deeply and make their critical thinking skills better (Wang \& Posey, 2011). Moreover, improving critical thinking skills in the learning process helps students improve their learning outcomes in the classroom (Bahmani, 2016).

Table 8. ANCOVA test

\begin{tabular}{clll}
\hline Variable & F & Sig & Partial eta Square \\
\hline All Class & 120.52 & 0.000 & 0.683 \\
\hline
\end{tabular}

Learning activities using inquiry-guided based ecosystem modules can improve students' critical thinking skills because they can train students to engage in active learning by (1) interacting with other fellow students, (2) making the learning process more interesting by focusing on direct observations in the field, (3) obtaining observational data, and (4) discussing it through presentation activities before the class along with the teacher's guidance. The applied guided inquiry-based learning on the module provides better students' learning outcomes value. Various research results show that the application of guided inquiry-based learning has a positive trend especially in learning that emphasizes the active participation of students in thinking and concluding (Vlassi \& Karaliota, 2013). Critical thinking skills include a person's ability to analyze and evaluate, have strong ideas and arguments, think consciously and responsibly (He, Craig, \& Wen, 2013).

Learning activities using guided inquiry-based ecosystem modules motivate students to actively engage in learning because they place them as a center of learning activity, students not only learn something but also actively discover, do, pay attention/observe, and experience the activity of learning in the guidance of the teacher as a motivator and facilitator in learning (Simbolon \& Sahyar, 2015). Guided inquiry-based learning activities can improve students' critical thinking skills because when the learning process takes place, students develop their knowledge by facilitating their brains to think Rajagukguk and Simanjuntak (2015) through discovery-based learning and centering on themselves with teacher guidance in the learning process.

\section{CONCLUSION}

Guided inquiry-based ecosystem modules are developed based on guided inquiry syntax, and aspects of critical thinking skills are appropriate to be used in the learning process. The effectiveness of the module developed was shown by the results which obtained that there was a significant difference between the critical thinking skills of students in the experimental class and the control class. This difference shows that the module developed is better at empowering students' critical thinking skills compared to the textbooks used in schools.

\section{REFERENCES}

Abdi, A. (2012). A study on the relationship of thinking styles of students and their critical thinking skills. Procedia-Social and Behavioral Sciences, 47, 1719-1723. doi: https://doi.org/10.1016/.sbspro.2012. 06.889

Adeyemi, S. B. (2012). Developing critical thinking skills in students: A mandate for higher education in Nigeria. European Journal of Educational Research, 1(2), 155-161. Retrieved from https://files.eric.ed. 
gov/fulltext/EJ1086348.pdf

Aizikovitsh-Udi, E., \& Cheng, D. (2015). Developing critical thinking skills from dispositions to abilities: Mathematics education from early childhood to high school. Creative Education, 6(4), 455-462. doi: https://doi.org/10.1016/j.sbspro.2013.01.031

Aliakbari, M., \& Sadeghdaghighi, A. (2013). Teachers' perception of the barriers to critical thinking. Procedia Social and Behavioral Sciences, 70, 1-5. doi: https://doi.org/10.1016/j.sbspro.2013.01.031

Arslan, S. (2015). Investigating predictive role of critical thinking on metacognition with structural equation modeling. The Malaysian Online Journal of Educational Science, 3(2), 1-10. Retrieved from http:// ijie.um.edu.my/index.php/MOJES/article/view/12690

Bahmani, S. (2016). Improved critical thinking in students using current events journaling. International Journal of Sociology and Social Policy, 36(3/4), 190-202. doi: https://doi.org/10.1108//JSSP-04-20150038

Bensley, D. A., \& Spero, R. A. (2014). Improving critical thinking skills and metacognitive monitoring through direct infusion. Thinking Skills and Creativity, 12, 55-68. doi: https://doi.org/10.1016/j.tsc.2014.02.001

de Bie, H., Wilhelm, P., \& van der Meij, H. (2015). The Halpern critical thinking ssessment: Toward a Dutch appraisal of critical thinking. Thinking Skills and Creativity, 17, 33-44. doi: https://doi.org/10.1016/j.tsc. 2015.04.001

Dwyer, C. P., Hogan, M. J., \& Stewart, I. (2014). An integrated critical thinking framework for the 21 st century. Thinking Skills and Creativity, 12, 43-52. doi: https://doi.org/10.1016/j.tsc.2013.12.004

Elisanti, E., Sajidan, S., \& Prayitno, B. A. (2018). The effectiveness of inquiry lesson-based immunity system module to empower the students' critical thinking skill. EDUSAINS, 10(1), 97-112. doi: https://doi.org/ 10.15408/es.v10i1.7259

Facione, P. A. (1992). Critical thinking: What it is and why it counts. Insight assessment. Retrieved from https://www.insightassessment.com/CT-Resources/Teaching-For-and-About-Critical-Thinking/CriticalTh inking-What-It-Is-and-Why-It-Counts/Critical-Thinking-What-It-ls-and-Why-lt-Counts-PDF

Gall, M. D., Gall, J. P., \& Borg, W. R. (2003). Educational research: An introduction, 7th edition. Educational Research: An introduction. New York: Pearson A\&B Education. Retrieved from https://www.pearson. com/us/higher-education/product/Gall-Educational-Research-An-Introduction/978032108189 6.html

Gengarelly, L. M., \& Abrams, E. D. (2009). Closing the gap: Inquiry in research and the secondary science classroom. Journal of Science Education and Technology, 18(1), 74-84. doi: https://doi.org/10.1007/s 10956-008-9134-2

He, H., Craig, R., \& Wen, J. (2013). Developing critical thinking skills and effective co-operative international accounting degree programs in China. Asian Review of Accounting, 21(2), 144-159. doi: https://doi.org/ 10.1108/ARA-04-2012-0017

Ismail, N. S., Harun, J., Zakaria, M. A. Z. M., \& Salleh, S. M. (2017). The effect of mobile problem-based science dictionary application dicscience PBL towards students' mastery of scientific terms and critical thinking. In 2017 International Conference on Learning and Teaching in Computing and Engineering (LaTICE) (pp. 69-75). IEEE. doi: https://doi.org/10.1109/LaTiCE.2017.19

Jiun, L. T., \& Nurzatulshima, K. (2014). Inquiry in learning. International Journal of Technical Research and Applications, 10, 61-65. doi: https://doi.org/10.1007/978-1-4419-1428-6_4377

Lai, E. R. (2011). Critical thinking: A literature review. Retrieved from https://images.pearsonassessments. com/images/tmrs/CriticalThinkingReviewFINAL.pdf

Larsson, K. (2017). Understanding and teaching critical thinking - A new approach. International Journal Of Education Research, 84(May), 32-42. doi: https://doi.org/10.1016/j.ijer.2017.05.004

McKenney, S., \& Reeves, T. C. (2014). Educational design research. Handbook of Research on Educational Communications and Technology: 4th Ed, 131-140. doi: https://doi.org/10.1007/978-1-4614-31855_11

Nisa, E. K., Koestiari, T., Habibbulloh, M., \& Jatmiko, B. (2018). Effectiveness of guided inquiry learning model to improve students' critical thinking skills at senior high school. Journal of Physics: Conference Series, 997(1), 12049. doi: https://doi.org/10.1088/1742-6596/997/1/012049

Nusarastriya, Y. H., Sapriya, H., Wahab, A. A., \& Budimansyah, H. D. (2013). Pengembangan berpikir kritis dalam pembelajaran pendidikan kewarganegaraan menggunakan project citizen. Jurnal Cakrawala Pendidikan, 3(3), 444-449. doi: https://doi.org/10.21831/cp.v3i3.1631

Onions, P. (2009). Thinking critically: An introduction. Leeds. Retrieved from http://www.patrickonions.org/ docs/academic/2009 Thinking critically.pdf

Prihatin, P., Prayitno, B. A., \& Rinanto, Y. (2017). Pengembangan modul berbasis inkuiri terbimbing pada 
materi jamur untuk meningkatkan kemampuan berpikir kritis siswa kelas X SMA Negeri 1 Cepogo Boyolali. Jurnal Inkuiri, 6(1), 75-90. doi: https://doi.org/10.20961/inkuiri.v6i1.17268

Rajagukguk, W., \& Simanjuntak, E. (2015). Problem-based mathematics teaching kits integrated with ICT to improve students' critical thinking ability in junior high schools in Medan. Jurnal Cakrawala Pendidikan, 3(3), 347-356. doi: https://doi.org/10.21831/cp.v3i3.7342

Rufii, R. (2015). Developing module on constructivist learning strategies to promote students' independence and performance. International J. of Education, 7(1), 18-28. doi: https://doi.org/10.5296/ije.v7i1.66 75

Rusche, S. N., \& Jason, K. (2011). "You have to absorb yourself in it": Using inquiry and reflection to promote student learning and self-knowledge. Teaching Sociology, 39(4), 338-353. doi: https://doi.org/10.1177 10092055X11418685

Sarigoz, O. (2012). Assessment of the high school students' critical thinking skills. In Procedia - Social and Behavioral Sciences (Vol. 46, pp. 5315-5319). doi: https://doi.org/10.1016/j.sbspro.2012.06.430

Serrat, O. (2017). Critical thinking. In Knowledge Solutions (pp. 1095-1100). Singapore: Springer. doi: https://doi.org/10.1007/978-981-10-0983-9_125

Setiyadi, M. W., Ismail, I., \& Gani, H. A. (2017). Pengembangan modul pembelajaran biologi berbasis pendekatan saintifik untuk meningkatkan hasil belajar siswa. Journal of Educational Science and Technology, 3(2), 102-112. doi: https://doi.org/10.26858/est.v3i2.3468

Shehab, H. M., \& Nussbaum, E. M. (2015). Cognitive load of critical thinking strategies. Learning and Instruction, 35, 51-61. doi: https://doi.org/10.1016/j.learninstruc.2014.09.004

Simbolon, D. H., \& Sahyar, S. (2015). Pengaruh model pembelajaran inkuiri terbimbing berbasis eksperimen riil dan laboratorium virtual terhadap hasil belajar fisika siswa. Jurnal Pendidikan Dan Kebudayaan, 21(3), 299-316. doi: https://doi.org/10.24832\%2Fjpnk.v21i3.192

Sukardjo, M., \& Sugiyanta, L. (2018). Analisis strategi pembelajaran matematika kurikulum 2013 dalam rangka meningkatkan nilai PISA matematika. JKPP: Jurnal Kesejahteraan Keluarga Dan Pendidikan, 5(1), 42-64. doi: https://doi.org/10.21009/JKKP.051.05

Tabačková, Z. (2015). Outside the classroom thinking inside the classroom walls: Enhancing students` critical thinking through reading literary texts. In Procedia - Social and Behavioral Sciences (Vol. 186, pp. 726731). doi: https://doi.org/10.1016/j.sbspro.2015.04.042

Thompson, C. (2011). Critical thinking across the curriculum: Process over output. International Journal of Humanities and Social Science, 1(9), 1-7. Retrieved from http://www.ijhssnet.com/journals/Vol._1_No. 9_Special_Issue_July_2011/1.pdf

Visande, J. C. (2014). Developing critical thinking skills among education students through formative education. International Journal for Cross-Diciplinary Subjects in Education (IJCDSE), 5(4), 1783-1789. Retrieved from https://pdfs.semanticscholar.org/62cb/b90e3ec7f2363e1bc7ffe9059e988e581839.pdf

Vlassi, M., \& Karaliota, A. (2013). The comparison between guided inquiry and traditional teaching method. A case study for the teaching of the structure of matter to 8th grade Greek students. In Procedia-Social and Behavioral Sciences (Vol. 93, pp. 494-497). Elsevier B.V. doi: https://doi.org/10.1016/j.sbspro.20 13.09.226

Waluyo, S., Prayitno, B. A., \& Sugiyarto, S. (2017). Pengembangan modul berbasis guided discovery pada materi jamur untuk meningkatkan kemampuan berpikir analitis. Jurnal Inkuiri, 6(1), 61-74. doi: https:// doi.org/10.20961/inkuiri.v6i1.17266

Wang, H., \& Posey, L. (2011). An inquiry-based linear algebra class. US-China Education Review, 4, 489 494. Retrieved from https://files.eric.ed.gov/fulltext/ED526792.pdf

Wilkin, C. L. (2017). Enhancing critical thinking: accounting students' perceptions. Education + Training, 59(1), 15-30. doi: https://doi.org/10.1108/ET-01-2015-0007

Zabit, M. N. M. (2010). Problem-based learning on students critical thinking skills in teaching business education in Malaysia: A literature review. American Journal of Business Education (AJBE), 3(6), 1932. doi: https://doi.org/10.19030/ajbe.v3i6.436 